\title{
Althusser's Structuralism \& a Theory of Class
}

\section{Introduction}

The potential benefits to Marxism of structuralism in its consciousness and avoidance, of many of the reductionist tendencies within Marxism seem to have been lost due to an arguably deficient theory of class struggle within structural Marxism. Situated in the strange position of being unappealing to Marxists for this perceived inadequacy and to non-Marxists for being Marxist, it has suffered from a lack of interest in recent years. For this reason, Poulantzas's work studying the state has traditionally been located within a debate between structuralism and instrumentalism with less regard given to the many class aspects it contains ${ }^{1}$. It is then the aim of this work to attempt to counter this inadequacy of structural Marxism and to set the foundation for a theory containing the interrelation of both structures and class. An assumption behind this is that a theory of class also requires a concept of subject to overcome the flaws in the structuralist theory.

This will be done through establishing an abstract foundation for a subject/ object dialectic. It is the purpose of this dialectic, in being used to defend a Marxist position, to have its basis in material reality. It should be noted that the terms subject and object introduced for this dialectic are not to be considered to contribute to a full theory on their own. Instead they will be used towards reinterpreting Sartre and his concepts in view of the dialectic. This will then allow a move towards a more concrete understanding of subject and object and their interrelation.

\footnotetext{
${ }^{1}$ Bob Jessop, The Capitalist State (Oxford: Martin Robertson \& Company Ltd., 1982) p. 154
} 
This re-examination of structural Marxism will firstly concentrate on the work of its founder, Althusser. The main ideas and concepts he put forward will be explained whilst detailing how they avoid many reductionist tendencies. A comparison to the work of Sartre will follow, who Althusser criticised as an idealist for “...[making] the mistake of believing that history is made by man” ${ }^{2}$. Although the two theories appear to be in opposition to each other, the aim here will be using the subject/object dialectic to create a synthesis of the two. This is because Althusser's theory can be seen as giving a fuller explanation of the object as used by Sartre. In the course of this a criticism of structural Marxism, which removes any role of a subject, will be required. However this criticism is in order to strengthen the validity of the overall theory instead of refuting it.

Through this it should be possible to give structural Marxism an idea of subject that it lacks. Also, during the discussion reference will be made to Bourdieu who has proposed a theory uniting agent and structure similar to what is being aimed for at this point. Differences between Althusser and Bourdieu's concept of structure will be explained to show how they are not similar. This should expose the more dynamic role structures are given by Althusser.

From this foundation the idea of subject will be developed into that of class. Balibar's explanation of relations of production and the formation of class will be used to outline a structural explanation. An attempt will be made to overcome the problems structural Marxism has in continuing an understanding of class by using ideas of

\footnotetext{
2 Mark Poster, Existential Marxism in Postwar France (Princeton: Princeton University Press, 1975) p. 354
} 
Sartre. After establishing the basic ideas of class the discussion will move on to examining the interrelation of the economic structure and class. From this it should be possible to conclude how the two interact and continue this into the political structure.

For examining the political sphere the work of Poulantzas will be introduced. This will involve not only how he sees class relations but also the role of the state. Furthermore, his belief that politics under capitalism has a more independent role will be considered. Criticisms of this work will then be considered before accepting a modified version of Poulantzas to build upon this work.

The criticism of Bob Jessop will then be evaluated. Although a strong supporter of Poulantzas, Jessop makes the criticism that the weaker aspects of Poulantzas's theory are created by his earlier use of structuralism. This will then allow not only a further examination of Poulantzas's thinking but also a consideration of the basis of this work for uniting class with structure.

Finally it should be possible to see the effects a subject/object dialectic has on the reinterpretation of Althusser and Sartre, which will allow a progression onto class along with many other implications that an idea of subject has upon structures. Through this re-examination of these theorists a framework for a structural theory that can fully comprehend class, as well as being able to avoid any of the previous reductionist tendencies found within Marxism, is to be established. 


\section{The Subject/Object Dialectic and Sartre}

It is required then to outline a foundation of what constitutes the subject/object dialectic. This will be done by firstly defining subject and object and then explaining the relationship between them. Therefore it becomes a necessity to distinguish subject and object, to separate the two.

Subject shall be defined as any agent that possesses a power to act. This leaves the basis of subject deliberately ambiguous in that it will be applied not only to individuals but also groups, classes and other collective agents such as governments. This will allow the work to avoid unnecessary argument that could potentially distract from its aim, i.e. the level of power each individual subject that constitutes a political actor has. This does not mean that references to such areas will be left out but that they will not be explored in detail. Subjects can then be separated from objects in that an object does not have decision-making power. The terms subjective and objective will be used to indicate whether what is under investigation has the qualities of a subject or an object respectively.

Bukharin similarly makes this separation by stating, "the real world itself became an object, that is, the topic of human practice and thought” historically ${ }^{3}$. This manages to give a better idea of 'power to act' in that it defines object in relation to subjective “practice and thought”. Furthermore, it is important for the understanding of subject since two concepts have been created from it. Firstly, 'thought' which resides within the subject and, secondly, 'practice' where the subject acts upon the object. It needs

${ }^{3}$ Nikolai Bukharin, Philosophical Arabesques (New York: Monthly Review Press, 2005) p. 241 
to be noted that 'thought' is both passive and active. It is passive in the sense that it has been conditioned or as Marx put it "[developed] under definite conditions"4. It can also be considered as active in that it can reason and decide about how to practice.

The quotation from Bukharin's exposes the beginning of a relation between subject and object, as indicated with my emphasis, "the real world itself became an object". This highlights the point that the two concepts are interdependent, the one exists through its relation to the other. Bukharin reaches this conclusion and is quick to add that this does not mean the real world does not exist without a subject ${ }^{5}$. The emphasis now turns to the restriction of 'historically'. The term highlights the point that material reality exists but not as an object until the specific time in history when a subject arises. Consequently a subject relies on material reality, an object, to exist revealing the objective world as the more dominant factor in the interdependency.

This is in opposition to another possible situation where the subject is more dominant, for example Descartes' scepticism resulting in his famous "I am, I exist"6 which then requires the existence of a god to assure the subject of the experience of the objective world. Bukharin describes such scepticism as a separation of theory and practice ${ }^{7}$. It is a separation in that the theory says it is possible to deny the existence of the body but in practice food is required to keep alive. This further shows a domination of object over subject as the body itself can be seen as an object which the subject requires in order for thought and practice. Trotsky explains this another way with “consciousness grew out of the unconscious, ... the organic world out of the

\footnotetext{
${ }^{4}$ Karl Marx \& Friedrich Engels, The German Ideology (New York: Prometheus Books, 1998) p. 43

${ }^{5}$ Bukharin, Philosophical Arabesques, op. cit., p. 241

${ }^{6}$ René Descartes, Meditations and Other Metaphysical Writings (London: Penguin, 2000) p. 24

${ }^{7}$ Bukharin, Philosophical Arabesques, op. cit., p. 48
} 
inorganic”8. The historicity again is expressed by showing the stages that were progressed through to reach the possibility of subjects' existing. The body as the objective basis of a subject then also limits the latter's ability of thought and practice.

The second and third relations between object and subject are contained in the already given quotes of Marx and Bukharin respectively. The quote from Marx explains, subjective consciousness “[developed] under definite [objective] conditions”. Adding to what has already been said then, since the subjects' existence depends on material reality, including their bodies, this imposes certain thinking upon their consciousnesses, thus limiting it. Bukharin then expresses the active part of this relationship. Although the subject arises out of the object, in turn the object becomes the focus of "human practice and thought". The term for this activity of the subject can be found in another quote from Marx, through work the workers labour "presents [itself] as productive powers and forms of capital, of objectified labour" (my emphasis) ${ }^{9}$. This objectifying process of a subject acting upon an object, either mentally or physically, is referred to with the Marxist term praxis. The two terms, thought and practice, given by Bukharin are seen then as different aspects of praxis. This means that a subject is not powerless in its relations with an object and that it can use its praxis to create changes to material reality. The power to act then is nothing more than praxis.

The relation, therefore, is not one way but a dialectical exchange, with the objective material reality conditioning the subjective consciousness of mankind and, in turn,

\footnotetext{
${ }^{8}$ Leon Trotsky, “The ABC of Materialist Dialectics,” 1939

$<$ www.marxists.org/archive/trotsky/1939/12/abc.htm>, accessed 6 ${ }^{\text {th }}$ March 2007

${ }^{9}$ Karl Marx \& Friedrich Engels, Marx \& Engels Collected Works: Volume 34 (London: Lawrence \& Wishart, 1994) p. 121
} 
mankind acting upon material reality. Within this relationship material reality has been shown to be the more important since subjects could not exist without it and are conditioned by it. It is stressed, though, that this does not necessarily render subject useless since it possesses a power to act, its praxis.

However, there are two areas not yet covered in this understanding. These are interactions between subjects alone and objects alone. The former in one sense cannot truly exist. Since every subject must be a form of material entity, be that an individual, class or government, it appears as an object to all other subjects. Therefore a subject can be exercising its praxis on a second subject. The former will take the form to the second as though an object is interacting with it. Furthermore, the first subject will also see the second as an object for its praxis. A subject/subject relationship then is only a more complex subject/object relationship.

In contrast an object/object relationship in some respects is simpler than the former. This is because there is no subjective element to be taken into consideration. Without any subjects, objects will interact in patterns from which abstract laws can be made. In effect, the results from any interaction can be predicted unless there is a random element or the interaction is too complex for the current level of knowledge to understand. The most important part, however, is that objects interact according to laws; unless there is a random element to them which most science rejects. Therefore, any theory that does not give a place to a subject offers in essence a deterministic account of the process and final resultant of any given situation. 
Sartre's work, fortunately, contains both subjects and objects, although he does not describe them in this way. Being originally an existentialist who later turned to Marxism his theory deals primarily with the question of an individual's being. Due to this his work A Critique of Dialectical Reason begins by looking at the individual subject in material reality object. He stresses that the individual finds himself within material reality, thus agreeing with the materialist basis that other Marxist studies rest on ${ }^{10}$. From this he soon concludes that material reality acts upon individuals as well as individuals acting upon material reality through praxis ${ }^{11}$. This is in line with the interdependency that the dialectic showed to exist. Sartre places stress upon the dominance of the objective world by explaining that through the process of living the individual interiorises, is conditioned by, the exterior, the objective world ${ }^{12}$. This goes beyond the previous explanation given for the dialectic since it highlights that a subjective can only take a form that reflects the objective world it is in. This links back to the conclusion reached when examining Bukharin, that the material world limits subjective thought.

Sartre also introduces an interesting concept scarcity, to further the understanding of the point that the objective world is the more dominant in the relationship with his the subject. Scarcity has its basis in the fact that each individual while being a subject also has a body, which as mentioned appears to it as an object. This then imposes needs upon the individual to use its praxis towards keeping itself alive. It is then within a material world of scarcity that the individual "produces his [sic] life"

\footnotetext{
${ }^{10}$ Jean-Paul Sartre, Critique of Dialectical Reason: Volume 1 (London: Verso, 2004) p. 51

${ }^{11}$ ibid., p. 71

${ }^{12}$ ibid., p. 47
} 
amongst other individuals who are producing their own lives, and thus appear to each other as objects ${ }^{13}$.

Some Marxists would possibly criticise Sartre for using scarcity in this way since it is arguably going against how Marxists traditionally view need. This is that needs are a social creation and any discussion of what is scarcity can only be relative to the society or mode of production. The criticism, though, is not completely accurate. Marx did see needs as being socially created but also talked of basic needs as well as needs arising through society ${ }^{14}$. Scarcity does not necessarily have to come into contradiction with traditional Marxist thought. As basic needs are a link between the two and as Sartre notes that roughly seventy-five per cent of the world remains undernourished then the importance of scarcity in social relations is confirmed ${ }^{15}$. Furthermore, taking the socially created needs into account they too form a kind of scarcity within their society if unequally distributed, which is the case of the slave, feudal and capitalist modes of production.

Sartre introduces another new concept to Marxism that is also of use to the dialectic. This is the concept used to designate the history of a society, its practico-inert. While the dialectic as outlined above only shows the historicalness of the subject arising out of and conditioned by the objective world the practico-inert shows how subjects in a society arise out of and are conditioned by the society's previous and current praxis ${ }^{16}$. To elucidate, any subject in a conjuncture is conditioned by the previous praxis that created objects, like houses or added to society's knowledge etc, and current praxis

\footnotetext{
${ }^{13}$ ibid., p. 136

${ }^{14}$ Karl Marx, Capital: Volume 3 (England: Penguin in association with New Left Review, 1990b) p. 959

${ }^{15}$ Sartre, op. cit., p. 123

${ }^{16}$ ibid., p. 67
} 
that is creating more objects and interacting with the subject. It is the sum total of all lived experience. A certain amount of praxis is required then to maintain and reproduce society. Sartre describes this in a complex fashion through explaining that the "passive unity" of objects acting upon other objects enforces a "material unification” upon subjects ${ }^{17}$. Since these objects contain past praxis they enforce behaviour upon future praxis. This is then what leads to the reproduction of the “human order”. Sartre does not designate a term for this process. Therefore, for the purpose of this work, the reproduction of society through objects enforcing constraints upon a subject's praxis will be termed passive praxis. This term will serve useful in dividing praxis between that required for reproduction and active praxis, which is praxis towards further production. Marx makes a similar division but like Sartre does not designate a term for the process. Instead he talks of a certain amount of objectified labour being "absorbed... into the process of reproduction ${ }^{18}$.

With the dialectic outlined and used to categorise Sartre's work in a new way the same process will now be applied towards Althusser's form of Marxism. Attention will focus on the dialectic, and the consequences for not taking into consideration either the subjective or objective aspects. Firstly, however, it is required that Althusser's theory and its strengths are outlined.

\footnotetext{
${ }^{17}$ ibid., p. 184

${ }^{18}$ Karl Marx, Capital: Volume 1 (England: Penguin in association with New Left Review, 1990a) p. 1045
} 


\section{Althusser's Structuralism and Praxis}

Althusser rose to prominence from his responses to the release of Marx's "Early Works”, categorised through the fact that although released later than Capital they were actually written before it. In response to an apparent "humanist" interpretation found within these early texts, Althusser sought to respond by (a) defining an epistemological break ${ }^{19}$ between the "Early Works", which he saw as being humanist, and the "Mature Works" leading to (b) a close reading of the "Mature Works" to try to decipher the philosophy behind Marx’s work. It was from this combination of a strong anti-humanism and an attempt to extract Marx's method in his work, which he never wrote out in full detail, that Althusser arrived at his position that was labelled “structural Marxism”.

The reason this title was used for his work is due to his strong focus on the structures of a given social formation. By social formation, Althusser was referring to the whole of a given society. In other words, it includes every aspect of a society and not just a single mode of production that could only form part of the whole ${ }^{20}$. The structures for Althusser are the economy, political-judiciary and ideology, which he refers to as instances $^{21}$. Although Althusser at times appears to argue that these are almost taken a priori to an investigation of a social formation ${ }^{22}$. However both Poulantzas and Balibar set out from a different beginning. Instead they outline the three different instances but stress that there could be more taken into consideration if an adequate

\footnotetext{
${ }^{19}$ Louis Althusser, The Humanist Controversy and Other Writings (London: Verso, 2003) p. 268

${ }^{20}$ Louis Althusser, For Marx (London: Verso, 2005) p. 110

${ }^{21}$ ibid., p. 112

${ }^{22}$ E. P. Thompson, The Poverty of Theory and other essays (London: Merlin Press, 1978) p. 202
} 
difference is found between it and any other decided instance ${ }^{23}$. For example, the political and judiciary could be considered separate instances if it was proven that considering them as one, the politico-judiciary, was inefficient. It appears then that even Althusser's followers saw this undergird of his theory to contain a flaw and set out to supply an alternative that outlines three instances that a social formation can be divided into but which could also later be added to if deemed necessary.

Althusser stresses that these instances are not fully autonomous from each other and that they instead hold a relative autonomy ${ }^{24}$. By this he meant that changes to one instance would have possible repercussions for the others, therefore they are to be considered as "united but distinct" ${ }^{25}$. He does, though rule out one instance completely determining the others. A famous example of this idea would be economism, where everything is explained by reducing it to the economic instance ${ }^{26}$.

However, it is not meant that each of the instances are equal to the other. Althusser stresses that in every social formation there is a structure in dominance that is the most important to $\mathrm{it}^{27}$. Poulantzas gives the example of the political-judiciary within a social formation where the feudal mode of production is dominant. This does not mean that the political-judiciary is the instance that the feudal mode of production relies on. Poulantzas quotes Marx saying, "the Middle Ages could not live on Catholicism, nor the ancient world on politics”28. The reason for this lies with the last part of Althusser's concept of how the structures interact. The economic may not

\footnotetext{
${ }^{23}$ Nicos Poulantzas, Political Power \& Social Class (Great Britain: Verso, 1978a) p. 13; Louis Althusser, Louis \& Etienne Balibar, Reading Capital (Great Britain: Verso, 1979) p. 204

${ }^{24}$ Althusser \& Balibar, op. cit., p. 97

${ }^{25}$ Poulantzas, Political Power and Social Class, p. 16

${ }^{26}$ Althusser \& Balibar, op. cit., p. 111

${ }^{27}$ ibid., p. 319

${ }^{28}$ Poulantzas, Political Power and Social Class, p. 28
} 
always be the structure in dominance but it is always dominant in the last instance ${ }^{29}$. Therefore, the importance of the existence of a given social formation is dependent on its economic instance, which gives the society "the mode in which they [gain] a livelihood”30. This allows the economy to hold an importance it is generally given within classical Marxist thought, from which Althusser did not originally intend to radically differ ${ }^{31}$, without resulting in determinism. To explain why the division of society into instances avoids determinism, Althusser explained that the instances and their interaction expose how a social formation is overdetermined ${ }^{32}$. By this he meant that, similarly to Mao's discussion of a complex dialectic, there was a multiplicity of determinants that contribute to society and not just one. The example Althusser used of a single determinant was Hegel's mater/slave dialectic. Instead of examining the richness of societies Hegel had a tendency to relegate it all into a constant continuation of the master and slave relation ${ }^{33}$.

Furthermore, overdetermination adds to the idea of base and superstructure. With the economic instance, the base, being dominant in the last instance, the politicaljudiciary and ideological instances, the superstructure, within certain social formation or modes of production can be the structure in dominance without destroying the metaphor that the base gives rise to the superstructure.

Other "reductionist" tendencies within Marxism that Althusser was aiming to avoid were mechanism and voluntarism. Jessop would classify these theories as capital-

\footnotetext{
${ }^{29}$ Althusser \& Balibar, op. cit., p. 203

${ }^{30}$ Poulantzas, Political Power and Social Class, 28

${ }^{31}$ Poster, op. cit., p. 342

${ }^{32}$ Althusser, For Marx, p. 206

33 ibid., p. 101
} 
theoretical and class-theoretical respectively ${ }^{34}$. This is due to the first focusing on the laws of motion of capitalism as the basis of its theory and the second focusing instead upon classes and the class struggle. In terms of the subject/object dialectic the concentration of the first is upon objects and the second upon subjects. Obviously this results in the theories being inadequate at providing a theory of society.

Mechanism, which Althusser associates with the Second International ${ }^{35}$, thus results in a teleological view that capitalism is destined to be transcended by socialism. This deterministic interpretation of Marxism was in Althusser's view replaced by voluntarism with ideas like Gramsci’s “philosophy of praxis”36. The problem here is that this places too much emphasis on "actor-subjects" that write their own history at the expense of understanding how they exist and are conditioned within material reality; the objective world. Althusser in response accuses such theories of being at fault of humanism or historicism; or, even worse, both $^{37}$. Humanism because of being class-theoretical with a potential to include ethics within the theory; and historicism as there is a tendency from the importance given to class struggle to look at previous struggle to define the current conjuncture. A conjuncture being the balance of all contradictions and over determinations at any given moment. It thus ignores the importance of structures on the conjuncture.

This, then, makes the practico-inert dangerously close to another aspect of historicism. If everything is grouped together under the practico-inert then this ignores the effects of structural determination that the instances have upon a social

\footnotetext{
${ }^{34}$ Jessop, op. cit., pp. 8-9

${ }^{35}$ Althusser \& Balibar, op. cit., p. 119

${ }^{36}$ ibid., p. 120

37 ibid.
} 
formation and its qualitive form / modality. Althusser directly criticises Sartre on a point close to this ${ }^{38}$. As will be explained in the next section, structural Marxism provides an explanation of how the relations of production and social relations of production determine the mode of production. As everything is grouped together in the practico-inert this does not reflect the modality of social formations and is incapable of defining whether a period of time is dominated by a feudal or capitalist mode of production ${ }^{39}$.

Althusser's theory, as mentioned above, aims to oppose the move towards voluntarism without returning to the determination of mechanism. A problem arises here, namely that by removing all possibility of a "radical subject" the question arises whether he has actually successfully opposed voluntarism without returning to a new kind of mechanism. By having no subjects a backdoor for mechanism is created, as the world consists of only object/object relations whose processes are governed by laws of movement due to there being no subjective elements which through praxis can change the objects.

Althusser's work is however not completely without mention of subjects. Despite this, there appears to be a strange contradiction between his ideas of different practices, where people are seen to be in some form active ${ }^{40}$, and the use of the terms supports and bearers of structures to refer to humans within a social formation ${ }^{41}$. Overall, the latter appears to be the opinion he prefers to put forward. He goes as far as describing the structures of society as the true subjects of history, due to their being

\footnotetext{
${ }^{38}$ ibid., p. 136

${ }^{39}$ ibid., p. 172

${ }^{40}$ Louis Althusser, Lenin and Philosophy: and other essays (New York: Monthly Review Press, 2001) p. 31

${ }^{41}$ Althusser \& Balibar, op. cit., p. 180
} 
the most important aspect of social formations. He is quick, though, to mention that they do not act like actual subjects because they are based on "relations"42. In respect to the subject/object dialectic then the structures of a social formation can be categorised as objective in nature. It is interesting to note that Althusser prefers to use the term 'practice' instead of the Marxist term 'praxis' to describe human action. This is likely due to a desire to avoid any previous connotations of praxis and put practice forward as the result of human action due to structures.

It appears that an adequate idea of subject cannot be found within Althusser's work to prevent it from becoming deterministic. Although he does mention subjects and human activity these soon become superfluous by their reduction to the level of structures. Structural Marxism, by separating social formations into three instances and explaining their interactions as "united but distinct", provides an opposition to strongly reductionist, determinist and voluntarist theories. Despite this greater flexibility in its interpretation of social formations it still remains in need of an idea of subject to be fully able to remain non-mechanist.

In response to similarly perceived problems, Mark Poster proposes that Sartre’s form of Marxism should be seen as a negation of Althusser's and be used to also examine society $^{43}$. However, this is problematic in itself. The use of two different theories to study society can result in two very distinct interpretations. Instead of using both at once what is needed is a synthesis of the two in order to form the creation of a single theory.

\footnotetext{
${ }^{42}$ ibid., p. 180

${ }^{43}$ Poster, op. cit., p. 360
} 
Fortunately, there is an area that Althusser and Sartre agree on, although neither appeared conscious of the other doing so. The area of convergence is towards the complexity of social formations. The two approach this from different ways but the conclusion is the same: that there are forms of Marxism that remove the complexity from their studies and provide inadequate accounts of the processes at work. Both attacked the theories that only took account of the proletariat and bourgeoisie in the capitalist mode of production (CMP). While agreeing that they are normally the most significant in the CMP, the ignoring of other classes and their relative strengths and weaknesses makes Marxism lifeless and stuck at a level of abstraction from concrete reality.

Althusser identified the problem as Hegelian. This is due to its being similar to Hegel's concept of a single contradiction that forms the essence of each society ${ }^{44}$. Sartre, on the other, hand blamed the problem on lazy Marxism ${ }^{45}$, which uses previous categories to label the area under consideration without undertaking any serious study. Despite this difference in the diagnoses of the problem, both wished Marxist theory to be able to fully understand the complexity of society and any Marxist study of a given conjuncture to make adequate study of its concrete reality and not engage in a process of explaining it away in reference to previous works or abstractions. As already shown, Althusser lacks an idea of subject that limits his theory and Sartre's work does not contain the same benefits that Althusser's structuralism theory has towards opposing reductionism.

\footnotetext{
${ }^{44}$ Althusser, For Marx, p. 101

${ }^{45}$ Sartre, op. cit., p. 44
} 
Even though the two theorists are in agreement in regard to the complexity of society, making a synthesis easier, it is not enough to begin a synthesis. This is due to Althusser taking structures as his starting point whereas Sartre's beginning is with individuals' being and their praxis. It is required that a method is found to allow the existence of praxis within structures. Bourdieu who took influences from Marxism ${ }^{46}$ has already undertaken an attempt similar to this by creating a theory of structure and agency. An example of this is with any field of science. For an agent, an individual subject, to become active within the field it firstly needs to be educated in the field to an adequate level to partake in it. After this it can work with the previous knowledge towards the goal of discovering new knowledge ${ }^{47}$. This is what Bourdieu termed habitus. In regard to this work habitus is in many ways comparable to the understanding of praxis so far given.

An immediate comparison can be made here with Sartre's discussion of language. Using it as an example of part of the practico-inert, Sartre explained that with language being a social construction it has been developed through the interaction of different individuals over time. Each new individual has to learn the words and grammar of the society's language in order to efficiently interact with the rest. In the process of living and the development of society new words make an appearance either through a change to a previous word or an altogether new word appearing from necessity ${ }^{48}$. Without using the term structure Sartre presents a theory that reflects Bourdieu's understanding in many ways. The difference is that Bourdieu has divided

\footnotetext{
${ }^{46}$ Pierre Bourdieu \& Jean-Claude Passeron, Reproduction in Education, Society and Culture (London: Sage, 2000) p. 4

${ }^{47}$ Pierre Bourdieu, Science of Science and Reflexivity (Cambridge: Polity Press, 2006) pp. 40 - 44

${ }^{48}$ Sartre, op. cit., p. 98
} 
areas of society according to field whereas Sartre refers to it collectively as practicoinert and makes divisions when necessary.

Although this shows Sartre had an understanding similar to Bourdieu of structure and praxis it is of importance that this does not mean the synthesis has been rendered unnecessary. Both Bourdieu and structural Marxists focus upon structures in their theory. Despite this, the theorists' ideas of structures are not the same. Poulantzas makes this clear with his criticism of Bourdieu. Structures in Bourdieu's theory do not have the same dynamic to them that is contained in structural Marxism ${ }^{49}$. Where structural Marxism has three different instances and explains how they interact and have varying levels of relative autonomy this is not found within Bourdieu's work. Interestingly his work instead appears similar to Althusser's idea of how a proper history of science should be ${ }^{50}$.

While Bourdieu's interpretation of structures is to be disregarded, the way in which Sartre's work was compared to it sheds light upon how to carry out a synthesis. This was that Sartre took language from the practico-inert in order to explain it. It is due to the practico-inert being the unification of all praxis that Sartre is able to then extract certain areas from it. From this knowledge it becomes easier then to create the foundation of a synthesis. The practico-inert when explained this way is comparable to the term conjuncture. Both terms refer to the state of a society at a given moment. Since, when structural Marxists use conjuncture, it is assumed that the overdetermination of the instances are deciphered along with other contradictions, all that Sartre's practico-inert does not contain is the overdetermination of the instances.

\footnotetext{
${ }^{49}$ Poulantzas Political Power \& Social Class, p. 61

${ }^{50}$ Althusser \& Balibar, op. cit., p. 135
} 
However, structural Marxists appear not to have any theory of the calculation of the balances of the other contradictions that the practico-inert provides. By examining the overdetermination of the structures, then, along with the practico-inert, a better understanding of a conjuncture can be reached. As it was possible to extract language from the practico-inert then it is realistically possible to divide it similarly as structural Marxists divide a social formation into instances. The different modes of production dominant within each of the social formations would enforce different kinds of praxis upon the individual members. Furthermore, with structuralism providing a form of modality the practico-inert can then be used to examine the other contradictions at a specific moment in time.

Although this approach divides the practico-inert into the three instances and posits the individual subjects into it, it remains at a level of abstraction from the concrete reality that Marxism is known for taking into strong consideration. This is classes and the class struggle. It is through examining how structural Marxism explains modes of production that its method of explaining classes is to be found. Along with this attention needs to turn to (a) a reworking of the practico-inert to contain modality and (b) the carrying through of the implications of subjects and praxis into the areas of structural Marxist theory that deal with classes and the class struggle. 


\section{Class: Form and Function}

A beginning towards how Marxists traditionally see class can be seen in a discussion between Marx and Proudhon. Examining what it is that creates a master and slave Marx arrives at the conclusion that both are abstractly human but remain a master and "a slave in and through society" [my emphasis] ${ }^{51}$. The importance for what this means surfaces from the use of the phrase "in and through". It is only in society that a class finds its basis for existence and is a class through the workings of society. For any understanding of class then study has to turn towards society. Within the study it needs to detail which aspects of society divides it into the different classes and ensures that they live as classes.

Class is an area that Sartre has difficulty with. The strong focus upon individuals with no clear explanation of their class is a potential problem. This could be perhaps why his work aimed towards discussion of the formation of groups and series ${ }^{52}$ instead of class. It is the formation of these that Sartre sees as important for the class struggle ${ }^{53}$. However, despite this no full outline of the formation of classes is given. The closest Sartre comes towards an explanation of class formation is to say that it is tied to the mode of production ${ }^{54}$. Although Sartre refers to collectives, groups, group-in-fusions and institutions all these for this work are to be considered the same. The main difference between them arises from the organisation of the individuals inside them.

\footnotetext{
${ }^{51}$ Karl, Marx, A Contribution to the Critique of Political Economy (England: Penguin, 1973) p. 259

${ }^{52}$ Sartre, op. cit., p. 65

53 ibid., p. 65

${ }^{54}$ ibid., p. 737
} 
However since this work is concerned with an outline towards an idea of subject in structural Marxist the strong individual focus can be put aside.

Balibar in his section of Reading Capital lays out a method for examining the relations that exist in society and how these create classes. Given that the economic is dominant in the last instance it is within the relations of production that Balibar sees classes being formed. Not only do the relations of production give classes their form but also determine the mode of production ${ }^{55}$. This could then show why, with a poor understanding of class, Sartre's theory also lacks modality. It is, therefore, through the examination of different relations of production that different economic epochs can be established. Balibar, through a reading of Marx, extracts three elements and two "connexions". The three elements are labourers, means of production and nonlabourers. The connexions are a "property connexion" and a "material appropriation connexion" ${ }^{56}$. Elsewhere these connexions are referred to as the relation of production and the social relation of production respectively. It is the relation of ownership of the means of production between the labourers and the non-labourers that determines the property connexion. The relation of the product of labour from the means of production to the labourer and non-labourer determines the material appropriation connexion ${ }^{57}$. Tomlinson stresses that the two connexions cannot be viewed as separate, but must instead be viewed as interdependent ${ }^{58}$.

Differences in these two connexions are what determine, for example, whether a mode of production is feudal or capitalist and the class form of the labourer and non-

\footnotetext{
${ }^{55}$ Althusser \& Balibar, op. cit., p. 212

${ }^{56}$ ibid., p. 213

${ }^{57}$ ibid., p. 214

${ }^{58}$ E. Tomlinson, 'Althusser, Balibar and Production', Capital and Class, No.4, (1978) pp. 127 - 128
} 
labourer. For example, in the capitalist mode of production the labourer does not own the means of production, first connexion, or the product of his labour, second connexion. By contrast in the feudal mode of production the labourer owns the means of production but the non-labourer appropriates part of the product of this labour. This is of benefit to an examination of the practico-inert. With praxis divided between passive praxis, used for reproduction, and active praxis, for further production of a society, or as Sartre terms it praxis for "re-constituting",59, it appears that society can only move in a slow evolutionary fashion. However, the qualitive difference that the relations of production enforce manages to add a revolutionary change to the nature of the practico-inert.

This has only achieved the result of showing how classes exist in society. Interestingly a return to Sartre can explain how classes exist through society, though the argument itself does not appear in his work. It is rather through applying part of his work onto structural theory that it becomes possible. The two connexions in creating classes through an objective passive unity enforce certain forms of praxis onto the classes as well. It is through objective constraints, then, that the individuals in a society live as classes. It can be seen, then, that changes in the relations of production would force a new form of praxis upon the individuals and thus change their class. The same can then be applied towards the instances and any change amongst them would also affect praxis.

It should be noted that re-constituting praxis is not completely compatible with passive praxis. For praxis to truly re-constitute a specific mode of production active

\footnotetext{
${ }^{59}$ Sartre, op. cit., p. 169
} 
praxis would also be required to ensure that the society continued within the mode of production. As Marx commented, in the end all that is required to reproduce capitalism is the continual reproduction of the proletariat and the bourgeoisie ${ }^{60}$. If praxis is not used towards this end, but instead towards the creation of new relations of production, then there will be a change in the mode of production. Reproduction, then, requires not only passive praxis but also active praxis that does not work towards changing the relations of production. As can be seen, there is a tension between structures shaping and affecting praxis and the potential for praxis to work towards changing the structures. This compliments what was found in the process of a subject/object dialectic where the subject is shaped by objective reality but can use its praxis to also act upon reality.

With an explanation for class complete, Althusser's theory comes across a problem with respect to the discussion of the class struggle. As mentioned, Althusser thought of structures as being the only potential subject in society. As individuals and classes can only be thought of as the supports or bearers of structures then it appears to be an argument that class struggle is only a realisation of the effect of structures upon them. During his explanation of the ideological instance Althusser again hints at subjects only being supports of structures ${ }^{61}$. Dismissing the ideas of false and true consciousness as a cancer within Marxism from the writing of the young Marx, he instead proposes that the determination of structures remains unconscious to those in a social formation ${ }^{62}$. It can be assumed from this, then, that any subjects' action is a result of structural determination. Form and function of classes then seems to rest entirely upon structural determination. It is questionable as to whether this can be

\footnotetext{
${ }^{60}$ Marx, Capital: Volume 3, p. 979

${ }^{61}$ Althusser, Lenin and Philosophy: and other essays, p. 115

${ }^{62}$ Althusser \& Balibar, op. cit., p. 180
} 
considered correct. In no part of the relations of production or the instances does a necessity for class conflict arise. The appearance of class conflict can only be found within the classes involved in conflict. Furthermore, carrying through this argument towards the explanation of the transitions between modes of production shows that it has become mechanistic, as it would have to be due to objective changes of structure with no subjective class struggle.

The cause of conflict may be external but it is an internal part of the subject that makes it use its praxis towards the class struggle. Structural Marxism does not make an attempt towards explaining this possible internal aspect since it would be seen as a return to humanism. It again falls upon Sartre to provide a solution, which comes in the form of scarcity, an external cause but one that the subject's very existence relies on. Scarcity is always internalised within the subject as a very real material necessity because of this. Structures will have an affect upon the level and distribution of scarcity. However, the structures are not what is internalised within the thoughts of the subject and influencing its praxis. This can only be done by scarcity itself. However scarcity does not guarantee class struggle, since it can just as much position labourers against each other as threats to their own existence. This is where the ideological instance needs to be taken into consideration. Both why labourers decide to stop seeing each other as threats and the form this takes, need to be examined. It is, then, Sartre who looks at this area.

With the opposition that workers can see towards each other as potential threats to their existence, existing as a series, then their praxis takes the form of reflecting inert 
matter $^{63}$. This is due to the individual's praxis being unable to challenge the passive unity that the practico-inert imposes upon it. It is, then, with the formation of groups that individuals can form a larger subject with a collective praxis giving it a level of freedom not found by the individual ${ }^{64}$. It is in this way that groups from the dominated class can form to challenge other groups and/or the structures; creating class struggle. This realisation of there being more strength in collective praxis gives rise to what could be called class-consciousness. This, interestingly, allows groups to be formed that do not contain all the members of a class or all members of the same class. In opposition to Althusser, it is not the structures that determine classconsciousness or lack of it but an ideological struggle by subjects against seeing each other as threats but instead seeing the benefit of collective praxis. A sympathetic reading of Althusser would note that he does stress the importance of ideological practice and struggle, but this is not enough to overcome the contradiction this has with his commitment to full structural determination. It is rather that while subjects are affected by the state of the ideological instance at that point in time, they also act inside it and through praxis change it.

It could be argued that class struggle is always existent within a given class society. For example a member of the proletariat and a member of the bourgeoisie are in constant struggle over wages; the former wanting an increase and the later a decrease. This though is imposed upon both, due to a passive unity caused by scarcity, in the form of not receiving enough to satisfy need for the proletariat and the threat of scarcity by being outdone by competitors for the bourgeois. While there is truth in the

\footnotetext{
${ }^{63}$ Poster, op. cit., p. 287

${ }^{64}$ Sartre, op. cit., p. 450
} 
argument that with scarcity there must also be some form of class struggle it is only when there is a collective subject or subjects whose praxis can efficiently challenge objects that class struggle reaches an observable point instead of reflecting the structures. This may perhaps be what Marx and Engels meant with their opening words in the Communist Manifesto that class struggle is "now hidden, now open"65.

Illustrative examples of what has just been argued can be found within the economic instance under capitalism. Assuming first of all that the individuals of the proletariat see each other as competitors then changes to their situation will result from economic changes. Marx explains this in the first volume of Capital. Looking at an increase of the number of potential workers it is easier to lower wages since there is a "reserve army of labour” needing work and the resulting competition between them will likely result in their being willing to work for less to secure a job ${ }^{66}$. The opposite happens with a decrease in the number of workers. This changes the balance of power between bourgeoisie and proletariat more in favour of the proletariat ${ }^{67}$. Since it is harder for a worker to be replaced then it becomes possible to demand a higher wage without the same risk of losing a job.

Forming a trade union then manages to secure more power for the proletariat. Most evidence shows that trade union members tend to earn more than non-trade union members. This is because the collective action of the workers in being able to all remove their praxis from the production process in the workplace makes it harder to ignore demands than what would happen on an individual basis. This does not guarantee however that any group will be effective in this way. The group has to put

\footnotetext{
${ }^{65}$ Karl Marx \& Friedrich Engels, The Communist Manifesto (London: Penguin, 2002) p. 219

${ }^{66}$ Marx, Capital: Volume 1, p. 781

${ }^{67}$ Marx, Capital: Volume 3, p. 763
} 
its praxis to efficient use and changes in the structures can change this. For example, even though not much has changed with respect to the workings of trade unions, the creation of the European Single Market has made it easier for managers to use the threat of moving business to challenge workers' demands ${ }^{68}$. It is for this very reason that Kim Moody wrote her work Workers in a Lean World to show how the increase of free trade and globalisation has had a negative effect upon workers' organisations and that new tactics need to be formulated ${ }^{69}$.

Sartre's work does not seem to include this; perhaps due to the originally static nature of the practico-inert, in comparison to the dynamic element structuralism can give it. This synthesis, along with the focus upon subjects and objects, has managed to transcend the dichotomy between being class- or capital-theoretical. The examples above have shown that the organisation of class, as well as the structural effect of capital both play a role within the determination of society. Class and capital thus oppose each other as subject and object and an understanding of both and their interaction is needed for a theory to be adequate. A theory that looked only towards class would be able to show how the balance of power between classes affects class struggle and show how the dominated class can fight for revolution, but by not looking at the tendency towards the concentration of capital it could not provide an understanding of the creation of monopoly capital. Reversing the situation, a theory focused upon capital could understand monopoly capital, but be unable to show why the organisation of trade unions managed to lead to wage increases or explain revolutions.

\footnotetext{
${ }^{68}$ David Shonfi Shonfield et. al., The Impact of the Internal Market on Pay and Collective Bargaining (Belgium: European Communities, 1997) p. 160

${ }^{69}$ Kim Moody, Workers in a Lean World: Unions in the International Economy (London: Verso, 1997) p. 180
} 
The objective nature of structures is what allows it to form the individuals within them into classes. It also imposes limits on the kind of praxis that is undertaken within it. However this does not mean that it determines function. The "ideal" function of the proletariat selling his labour to the bourgeoisie, who by buying the labour power of the proletariat can set the means of production into motion, can only exist by ignoring class struggle. Class struggle is not created by structures though they can have an effect on them. Rather, it is through scarcity that a reason for class struggle was found. It has been proven though that class struggle is dependent upon the organisation of classes and structural effects upon this organisation. This, though, has focused upon the ideological and economic instances; the political-judiciary still needs to be examined. 


\section{Class: Politics and the State}

Any examination of the political-judiciary cannot ignore the importance of the state within this instance but also its relation to other instances. Bukharin, commenting upon the beginning of a theory of state, makes clear the need to avoid too strong an emphasis upon the political-judiciary. In saying this he was arguing against Oppenheimer, who claimed that classes were a product of politics ${ }^{70}$. The phenomenon of emphasis being too strongly placed upon the political-judiciary is known as overpoliticisation. In contrast to Oppenheimer it has been shown that it is through the relations of production that classes are formed. This does not mean that classes only appear within economics however. Poulantzas stresses that classes exist in all instances ${ }^{71}$. Even though normally in a capitalist state everyone is seen as an individual there are still property laws reflecting the relations of production in which the capitalist is the owner of the means of production and the product. This establishes a link between the political-judiciary and the economic instances.

Structural Marxism seems to have a contradiction in its thinking when attention turns to the ideological instance. As already mentioned, Althusser, in parts of his work, stresses that subjects are determined by the instances and at other parts accepts an ideological struggle. Poulantzas, in his work, places focus on the second argument and builds upon it with Gramsci’s concept of hegemony. Hegemony takes as its basic argument that class society cannot be established completely through violent means

\footnotetext{
${ }^{70}$ Nikolai Bukharin, The Politics and Economics of the Transition Period (London: Routledge, 1979) p. 33

${ }^{71}$ Poulantzas, Political Power \& Social Class, p. 37
} 
and requires consent from the dominated ${ }^{72}$. This gives a new interpretation to Marx’s phrase that the "[t]he ideas of the ruling class are in every epoch the ruling ideas" ${ }^{73}$. Therefore, the acceptance of the relations of production under capitalism by the proletariat allows the bourgeoisie to accumulate surplus labour without as much resistance as it might otherwise have faced. It is due to this that a link between the three instances has now been established through the relations of production. Although at first appearing entirely economic it has been shown that they affect also the ideological and political-judiciary. A further understanding of the ideological instance and ideological struggle has also been given. It is a struggle against an ideology that not only keeps the workers isolated but also one that sees the current relations of production as natural or acceptable.

Sartre manages to further add to this in his discussion of lazy Marxists. Within certain parts of Marxism there is a tendency to assume that the bourgeoisie always has class-consciousness. Sartre instead argued that it is just as probable for the bourgeoisie to remain unconscious as the proletariat ${ }^{74}$. By this he meant that the bourgeoisie itself may believe the ideology that capitalism benefits everyone in society and not be deliberately trying to undermine all the proletariats' effort. Poulantzas takes a similar stance by stressing that a member of the bourgeoisie's short-term interest in increasing its own capital puts it at odds with the rest of the bourgeoisie $^{75}$. This is in opposition to instrumentalist theories that see the capitalist class as using the state as an instrument for their purposes.

\footnotetext{
${ }^{72}$ Antonio Gramsci, Selections from the Prison Notebooks (London: Lawrence \& Wishart, 1971) p. 12

${ }_{74}^{73}$ Marx \& Engels, The Communist Manifesto, p. 67

${ }^{74}$ Sartre, op. cit., p. 44

${ }^{75}$ Poulantzas, Political Power \& Social Class, p. 286
} 
Poulantzas sets out from the concept of instances and their interaction to examine the state. An interesting argument that further adds to the relation of the economic and political-judiciary instances arises as a foundation of the unique functioning of the capitalist state. Since the capitalist state is not needed for extra-economic coercion, due to its separation from the production process in the CMP, it has a greater level of autonomy ${ }^{76}$. All states in previous modes of production relied upon a stronger connection between the economic and political than does the capitalist state. In order that the accumulation of capital can continue, then, the role of the capitalist state is to organise the bourgeoisie in a power bloc, creating a long-term interest that they lack, and disorganise the proletariat. This is done through the state basing itself on a national-popular agenda ${ }^{77}$. Furthermore, this then allows it to make some concessions towards the proletariat against the wishes of certain parts of the bourgeoisie in order to secure the long-term existence of capitalism. Essentially it acts as a valve to release any build-up of pressure. This adds further weight against instrumentalism since the state does not act as a mere tool for the use of the ruling class.

The basics of Poulantzas's theory then work well in building upon the synthesis so far. He allows for the class struggle as well as looking at the effects of the structural matrix upon both the workings of structures and the classes in the social formation. However, within his further views on the class struggle a potential difficulty arises. In an essay On Social Classes he states that it is "only in the class struggle" that "social classes” are found ${ }^{78}$. This appears to be an overpoliticisation by Poulantzas, since he sees class struggle as being found on the level of the political-judiciary. Despite this,

\footnotetext{
${ }^{76}$ ibid., p. 255

${ }^{77}$ Jessop, op. cit., p. 154

${ }^{78}$ Nicos Poulantzas, 'On Social Class', New Left Review, No.78, (1973) p. 36
} 
though, attention needs to return to the wording of the terms. In his work Classes in Contemporary Capitalism published a year later, the term social class has been replaced with social force. It is only in the political instance that a class can become a social force ${ }^{79}$. However, only the terminology here is new to Marxist theory. As Rees explains, Marx saw a difference between the economic action of workers on strike against their employer "for a reduction in the working day" and the “qualitatively different [political] movement”, social force, of workers forming a general strike to change the law that decides the length of the working day ${ }^{80}$.

This then gives a better understanding of Poulantzas's theory of class factions, strata and categories $^{81}$. This is the idea that classes can be further subdivided, based on objective differences between members of the same class. Simon Clarke makes the criticism that the division of the classes is limitless, similar to Parmenides's criticism of Plato that the number of forms was limitless ${ }^{82}$, since there appears to be no definite qualifier for what constitutes objective differences ${ }^{83}$. For example, the coal and railway companies could be considered as different factions since the coal companies would want cheaper rail travel while the railway companies want prices as high as possible. This economic difference exists between every branch of industry as well as every company within the branches. Against this, though, objective difference can be qualified, as when the faction, strata or category takes the form of a separate social

\footnotetext{
${ }^{79}$ Nicos Poulantzas, Classes in Contemporary Capitalism (Great Britain: Verso, 1978b) p. 25

${ }^{80}$ John Rees, Algebra of Revolution: Dialectic and the Classical Marxist Tradition (London: Routledge, 1998) p. 8

${ }^{81}$ cf: Poulantzas, Political Power \& Social Class, p. 84

${ }^{82}$ Plato, The Plato Reader T. D. J. Chappell, (ed.) (Edinburgh: Edinburgh University Press, 1996) p. 243

${ }^{83}$ S. Clarke, 'Capital, Factions of Capital and the State: "Neo-Marxist” Analyses of the South Africa State’, Capital and Class, No.5, (1978) p. 35
} 
force through class struggle in the political instance. It is then different social forces and not classes that make up the power bloc.

Miliband finds a greater problem within Poulantzas's thinking. He believes that a backdoor for economism can be found within his work. This is because Poulantzas claims that state power is nothing more than "the power of a determinate class" ${ }^{84}$. If this is the case then the most powerful class economically would thereby become the class in power politically, similar to instrumentalism. Miliband believes this confusion arises from a confusion between state power and class power ${ }^{85}$. Sartre's concept of groups can highlight the problem. As previously discovered, groups do not need to consist of all the members of a class or even members of the same class. Looking at the class of voters although there is a tendency for each class to vote for a specific party it is by no means unanimous. Poulantzas then appears incorrect to directly link classes with social forces. As Jessop notes, Poulantzas, through making a direct linkage, ignores the ideological instance. This is not to argue that there is no link at all, instead an indirect link can be discovered. By establishing whose interest a social force represents its class character can be determined. It could then be established that a specific party's policies would most benefit monopoly capital even though a large percentage of its vote comes from the working class. A class, or faction, misidentifying their interests with those of another class; this is what is meant by false consciousness. Within the theorists considered, however, there is no attempt to make this connection between class and ideology determining the social forces.

\footnotetext{
${ }^{84}$ Ralph Miliband, 'Poulantzas and the Capitalist State’, New Left Review, No.82, (1973) p. 87

${ }^{85}$ ibid.
} 
Assuming that the above statement is correct it would then be possible to reply to the problem posed by Miliband. This is because the formation of social forces is dependant upon the state of the ideological struggle. Therefore unless during a period of strong class-consciousness, social forces do not necessarily reflect their members true interests. Furthermore, even a strong social force may be unable to act in the way it wants. For example, a social democratic party may be forced to accept cuts to the number of civil servant jobs during an economic crisis, since it is not committed to a revolutionary change to the economic instance. State power, then, is the power of the power bloc of social forces and the interests that they represent, in combination with any structural constraints imposed upon them. Class power is dependent upon the interaction of economic position, organisation and structural constraints as shown in the last section. Although it is possible for class power and state power to become nearly equivalent the two are not directly linked, as in instrumentalist theory.

Jessop believes that Poulantzas's use of both Gramscian and Althusserian concepts creates a tension within his theory. This is due to Gramsci's concepts tending to focus on class struggle whereas, as noted, Althusser is concerned with structures ${ }^{86}$, similar then to how this work has so far progressed. Jessop's reading of Poulantzas leads him to argue that there is a change over the course of his work from a structural explanation to one more focused on classes. He interprets this as a good move and sees the structural elements as the problem for Poultantzas's theory ${ }^{87}$. The rest of the criticisms from Jessop will be used for a dual purpose; both as a criticism of how Poulantzas's theory has been reinterpreted in this work and the basis in this work of the possibility of a subject/object dialectic.

\footnotetext{
${ }^{86}$ Jessop, op. cit., p. 181

${ }^{87}$ ibid., p. 187
} 
The first of the criticisms concerns the implications of the relative autonomy of the state if taken from both a structural and class struggle position. Since Poulantzas sees the precise form and degree of the relative autonomy as being based on the class struggle it seems to Jessop that Poulantzas is using two different approaches to describe the relative autonomy; one structural and the other conjunctural ${ }^{88}$.

However, Jessop could perhaps be basing this on a misunderstanding. The use of structural theory allows Poulantzas to explain the limits of the relative autonomy. For example, it is not until the CMP that the political-judiciary instance gains more autonomy from the economic instance. This then imposes a passive unity onto the subjects of the practico-inert / conjuncture. Praxis then is divided into passive praxis due to structural constraints and active praxis that in order for the full reproduction of a social formation must work within the limits of the structures. This allows a flexibility though, for praxis, as it can act within the structures or aim towards changing the relations of production and therefore the structural matrix. This is why without a change of structures both a social democratic or right wing party could be in power. This is because neither change the relations of production. They would have an effect on the practico-inert but not the modality. It is this aspect that Jessop has overlooked. The structures set the area that the subjects can work within, whereas the practico-inert is the exact level of the class struggle happening in these limits.

Applying this idea to the relative autonomy of the state, then what Poulantzas is saying is that it has a specific level of autonomy determined by the structures but at

${ }^{88}$ ibid., p. 183 
the same time, due to social forces, it acts in the interests of specific groups within the limits imposed. There are then the two kinds of relative autonomy; autonomy from the structures and autonomy from classes. However, these do not come into contradiction, as the latter is dependent upon the former. The difference, therefore, is that the first explains the relative autonomy that exists in all capitalist states whereas the second in combination with the first gives the relative autonomy within a concrete social formation.

Jessop's second criticism, then, can also be explained as a misunderstanding. He claims that Poulantzas sees that the policies of the capitalist state are in the short-term incoherent and contradictory, but in the long-term serve the interests of the bourgeoisie $^{89}$. This is based on a confusion of structural constraints and the praxis of social forces. It is the praxis of the different social forces that appears incoherent and contradictory. Through structural constraints, though, a passive unity commits praxis towards the reproduction of the social formation and gives an unconscious long-term policy of maintaining capitalism. This has been seen in the example of how a social democratic government, if not willing to take a revolutionary approach can go against its own ideals in a time of economic crisis. Jessop through categorising theories as being either capital or class theoretical has failed to realise that this division does not need to exist and prevents himself from comprehending how the two are interrelated.

\footnotetext{
89 ibid.
} 


\section{Conclusion}

Despite the fact that this work never intended to be a fully exhaustive examination it has managed to reach a number of useful findings and conclusions in regard to the theories examined. Furthermore, it has provided a start in relation to a structural theory that, through an understanding of subject, can also explain class.

From the beginnings of the subject/ object dialectic it was shown that material reality is dominant in its relationship with any subjects. However, subjects through their power to act, praxis, are able to in turn make changes upon material reality but are limited by their physical existence. It was shown that Sartre’s theory and his concepts could then be understood within this relationship.

Attention then turned to Althusser. The use of a dynamic structural theory managed to avoid economism. This was because each of the instances had their own relative autonomy and were not completely determined by the economic instance. Furthermore, under different modes of production there can be a different structure in dominance since it allows an explanation why in the feudal mode of production the political-judiciary held more importance than under the CMP, where the economic instance is in dominance. The structures due to this were said to be overdetermined, as no simple contradiction was the basis of any given social formation. This gives structural Marxism a large degree of flexibility for studying different social formations without any study becoming dependent upon solely empirical study. 
Voluntarism was ruled out of the theory since the importance of structures in forming a social formation had been proven. However, the opposite of this is mechanism. Althusser had not managed to completely avoid the simplicity found in mechanism, and, through the common feature of disregarding subjects both were found to be deterministic.

Sartre's practico-inert as originally envisioned was guilty of potential historicism since everything was lumped into the same historical category with no modality. However showing how the relations of production give classes their form along with the mode of production, its application onto the practico-inert gave it this modality. With no concept of subject and praxis that is not determined by the structures, structural Marxism could be interpreted as defining class struggle purely through the structures. However, synthesis with Sartre's theory allowed an explanation as to how the structures limit, through a passive unity, the praxis of subjects. Therefore class function is limited by structures but not determined by them.

It was also shown that scarcity was a cause of class struggle since it is internalised by individuals and affects their praxis. Groups then form, since individually praxis is unable to challenge the passive unity of other praxes, whereas a collective praxis can. The challenge maintained by groups against other groups or the relations of production is the class struggle. This idea that a group can change the relations of production prevents structural theory from being mechanist, giving it more flexibility as well as a better understanding of concrete reality. Examples then gave evidence of how changes in an instance can affect the efficiency of subjects' praxis. This relation 
of efficient praxis and structures affecting it was not found within either of the theorists, and is a benefit reached through the synthesis.

Turning finally to the political sphere it was shown how relations of production are reflected in law and are not entirely economic in nature. However, it is solely the relations of production that determine class form. Gramsci's theory of hegemony showed why the proletariat could give consent to capitalist relations. Despite this, though, the ideological instance did not appear to be adequately taken into account by Poulantzas, resulting in a problem of his theory that classes and social forces are directly linked. It was noted that groups do not necessarily need to be made up of members from the same class. It was then shown on the assumption that class and ideology determine the social forces, how social forces can represent specific class interests, but not be directly linked to the class they would benefit. This shows that the ideological instance still requires further examination in order to prove this assumption.

The rest of Poulantzas's theory, though, with this modification managed to avoid economism and instrumentalism. Economism was avoided since there is no direct link between class power and state power, because of there also being no direct link of class and social force. Instrumentalism was also avoided, since it was shown that the overdetermination of the structure under the CMP gave the political-judiciary instance a larger degree of autonomy.

Furthermore, it was shown how an understanding of structures and class is not impossible. This is based upon structures enforcing limits on classes. Classes can 
then work within the structural framework or work towards changing the relations of production creating a new overdetermination of the structures. This also manages to answer Jessop’s last criticism that the social forces in the capitalist state cannot be focused upon short-term interests with a long-term interest arising. The long-term interest of the state in maintaining capitalism, arising from structural constraints to prevent economic collapse, and therefore benefits the bourgeoisie. Any social force, then, that does not aim to change the relations of production, and thereby end the state as it exists, can only contribute to the long-term survival of capitalism.

The synthesis of Althusser and Sartre has managed to overcome the reductionist tendencies within both theories. Additionally, the combination of the two has also resulted in a greater level of flexibility. The foundation, and many benefits, of a structural Marxist theory that also contains a theory of class have been explained. This creates the possibility of a Marxist theory that is not reductionist and manages to maintain a level of flexibility that allows it to examine any given social formation without making itself too abstract. 